\title{
Spatial Distributions of Picoplankton and Viruses in the Changjiang Estuary and Its Adjacent Sea Area during Summer
}

\author{
Yun $\mathrm{Li}^{1,2}$ and Daoji $\mathrm{Li}^{2}$ \\ ${ }^{1}$ East China Sea Fisheries Research Institute, Chinese Academy of Fishery Sciences, Shanghai 200090, China \\ ${ }^{2}$ State Key Laboratory of Estuarine and Coastal Research, East China Normal University, Shanghai 200062, China
}

Correspondence should be addressed to Yun Li, salixly@yahoo.com.cn

Received 18 August 2011; Revised 16 September 2011; Accepted 28 October 2011

Academic Editor: Oscar Schofield

Copyright (C 2012 Y. Li and D. Li. This is an open access article distributed under the Creative Commons Attribution License, which permits unrestricted use, distribution, and reproduction in any medium, provided the original work is properly cited.

\begin{abstract}
Simultaneous determination of picoplankton (i.e., Synechococcus spp., Prochlorococcus spp., picoeukaryotes, and heterotrophic bacteria) and viruses in the Changjiang (Yangtze) River estuary and its adjacent sea area was made using flow cytometry during a cruise in June 2006. The results show that Prochlorococcus in all samples was below detectable level. The abundances of Synechococcus, picoeukaryotes, heterotrophic bacteria, and viruses ranged from 0.00 to $1.22 \times 10^{8}$ cell L $^{-1}, 0.01 \times 10^{6}$ to $1.42 \times 10^{7}$ cells $\mathrm{L}^{-1}, 8.40 \times 10^{7}$ to $4.29 \times 10^{9}$ cells $\mathrm{L}^{-1}$, and $1.20 \times 10^{7}$ to $1.06 \times 10^{10}$ particles $\mathrm{L}^{-1}$, respectively. The determined picoplankton groups and viruses distinctly increased with the distance off the estuary and where the maximum abundance that occurred in these groups was different somewhat due to the individual sensitivity to environmental changes. Viral abundance showed a positive correlation with salinity and negative correlations with turbidity and inorganic nutrient concentrations. Positive linear relations were found between Synechococcus, heterotrophic bacteria, and viruses.
\end{abstract}

\section{Introduction}

Autotrophic Synechococcus spp., Prochlorococcus spp., and picoeukaryotes, together with heterotrophic bacteria, are the principal components of marine picoplankton communities $(0.2-2 \mu \mathrm{m}$ in diameter) [1-4]. These picoplankton groups in the Changjiang estuary have been the subject of research in the past [5-14]. However, few data have been published on picoplankton community structure after the Three Gorges Dam construction. Previous studies were mainly focused on only one picoplankton group rather than simultaneously observing all picoplankton groups, and most of the data in the literature were obtained by epifluorescence microscope, which was not as efficient, sensitive, and precise as flow cytometry (FCM) adopted in this study $[12,13]$. Marie et al. [15] reported the method of FCM measurement on marine viruses, providing a glorious prospect on studying natural viral community. Compared with other oceanic regions, the field investigation on viruses in the Changjiang estuary was much less, and, up to now, only a few reports were found $[12,14,16,17]$.
With the construction of the huge Three Gorges Dam (height $180 \mathrm{~m}$, width $2 \mathrm{~km}$ ) in the middle reaches of Changjiang River, both the amount and the timing of the terrigenous input into the East China Sea will be different [18]. It has been suggested that after the water storage of the Three Gorges reservoir, light availability required for photosynthesis enhanced in the river mouth area due to less discharge of water and sediments from the river $[7,8]$. Studies indicate that picoplankton and viruses are more sensitive to environmental changes than larger organisms because of their small size $[19,20]$. Therefore, the quantifications of picoplankton and viruses are of great importance as it may reflect the changes in estuarine water quality associated with the construction of the dam.

In this study, a simultaneous determination of picoplankton groups and viruses was made in June 2006. The main objective is to observe the spatial distributions of picoplankton and viruses in the Changjiang estuary and its adjacent sea area and to discern the relationships between them and the environmental factors. 
TABLE 1: List of the measured environmental parameters in the Changjiang estuary and its adjacent sea area in June 2006.

\begin{tabular}{|c|c|c|c|c|}
\hline Parameter & Section I & Section II & Section III & Total station \\
\hline Number of sample & 39 & 45 & 15 & 96 \\
\hline \multicolumn{5}{|l|}{ Salinity (psu) } \\
\hline Range & $0.00-33.92$ & $14.86-34.42$ & $29.79-34.13$ & $0.00-34.42$ \\
\hline Mean \pm SD & $20.49 \pm 14.09$ & $30.13 \pm 4.41$ & $32.41 \pm 1.58$ & $26.62 \pm 10.69$ \\
\hline $\mathrm{CV}$ & $69 \%$ & $15 \%$ & $5 \%$ & $40 \%$ \\
\hline \multicolumn{5}{|l|}{ Turbidity (FTU) } \\
\hline Range & $0.07-122.13$ & $0.45-122.13$ & $0.00-32.43$ & $0.00-122.13$ \\
\hline Mean \pm SD & $57.84 \pm 57.09$ & $22.77 \pm 27.97$ & $3.68 \pm 8.29$ & $31.78 \pm 44.77$ \\
\hline $\mathrm{CV}$ & $99 \%$ & $123 \%$ & $225 \%$ & $141 \%$ \\
\hline \multicolumn{5}{|l|}{ Nitrate $\left(\mu \mathrm{g} \mathrm{L}^{-1}\right)$} \\
\hline Range & $11.89-1645.36$ & $19.47-342.04$ & $11.41-128.93$ & $11.41-1645.36$ \\
\hline Mean \pm SD & $493.43 \pm 503.65$ & $162.73 \pm 84.10$ & $45.65 \pm 38.18$ & $275.06 \pm 372.35$ \\
\hline $\mathrm{CV}$ & $103 \%$ & $52 \%$ & $84 \%$ & $135 \%$ \\
\hline \multicolumn{5}{|l|}{ Nitrite $\left(\mu \mathrm{g} \mathrm{L}^{-1}\right)$} \\
\hline Range & $0.11-34.44$ & $0.95-12.69$ & $0.11-11.55$ & $0.11-34.44$ \\
\hline Mean \pm SD & $5.70 \pm 6.86$ & $4.90 \pm 2.64$ & $3.31 \pm 3.21$ & $5.11 \pm 5.48$ \\
\hline $\mathrm{CV}$ & $120 \%$ & $54 \%$ & $97 \%$ & $107 \%$ \\
\hline \multicolumn{5}{|l|}{ Ammonia $\left(\mu \mathrm{g} \mathrm{L}^{-1}\right)$} \\
\hline Range & $3.62-63.93$ & $26.31-130.22$ & $17.97-123.74$ & $3.62-130.22$ \\
\hline Mean \pm SD & $39.23 \pm 17.28$ & $55.09 \pm 17.83$ & $56.20 \pm 25.69$ & $50.01 \pm 20.37$ \\
\hline $\mathrm{CV}$ & $44 \%$ & $32 \%$ & $46 \%$ & $41 \%$ \\
\hline \multicolumn{5}{|l|}{ Phosphate $\left(\mu \mathrm{g} \mathrm{L}^{-1}\right)$} \\
\hline Range & $2.53-43.57$ & $2.21-30.96$ & $0.98-12.45$ & $0.98-43.57$ \\
\hline Mean \pm SD & $17.90 \pm 11.91$ & $13.28 \pm 7.06$ & $5.34 \pm 3.14$ & $13.63 \pm 10.20$ \\
\hline $\mathrm{CV}$ & $67 \%$ & $53 \%$ & $59 \%$ & $75 \%$ \\
\hline \multicolumn{5}{|l|}{ Silicate $\left(\mu \mathrm{g} \mathrm{L}^{-1}\right)$} \\
\hline Range & $55.22-3027.20$ & $157.57-1144.37$ & $33.43-243.76$ & $33.43-3027.20$ \\
\hline Mean \pm SD & $936.83 \pm 898.12$ & $405.36 \pm 195.53$ & $151.69 \pm 69.83$ & $576.29 \pm 659.66$ \\
\hline $\mathrm{CV}$ & $96 \%$ & $48 \%$ & $46 \%$ & $114 \%$ \\
\hline
\end{tabular}

\section{Materials and Methods}

2.1. Field Sampling. The cruise was conducted from June 12 to 22, 2006, on board R/V Dong Fang Hong 2. Thirtytwo stations, between $29^{\circ} 00^{\prime} \mathrm{N}$ and $32^{\circ} 19^{\prime} \mathrm{N}$ and $120^{\circ} 46^{\prime} \mathrm{E}$ and $124^{\circ} 01^{\prime} \mathrm{E}$, were located along three different but representative sections identified as I, II, and III (Figure 1). Section I extended from the freshwater river to the saltwater sea covering the whole salinity gradient. Section II ran across the edge of the bar area and covered the whole river mouth. Section III represented the area off the river mouth. Water sample collections were guided by a Sea-Bird CTD (conductivity-temperature-depth) probe and carried out with Niskin bottles at three different depths (one meter below the surface, a few meters above the sea bed, and midway between, according to the depth at each station). Salinity and turbidity were recorded in the water column using the CTD assembly.

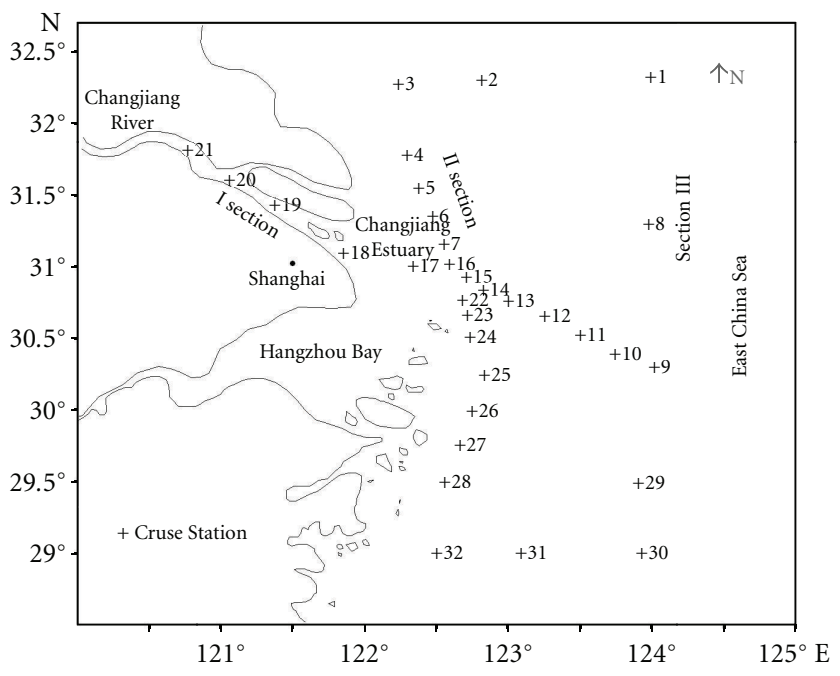

FIGURE 1: Location of sampling stations in June 2006. 


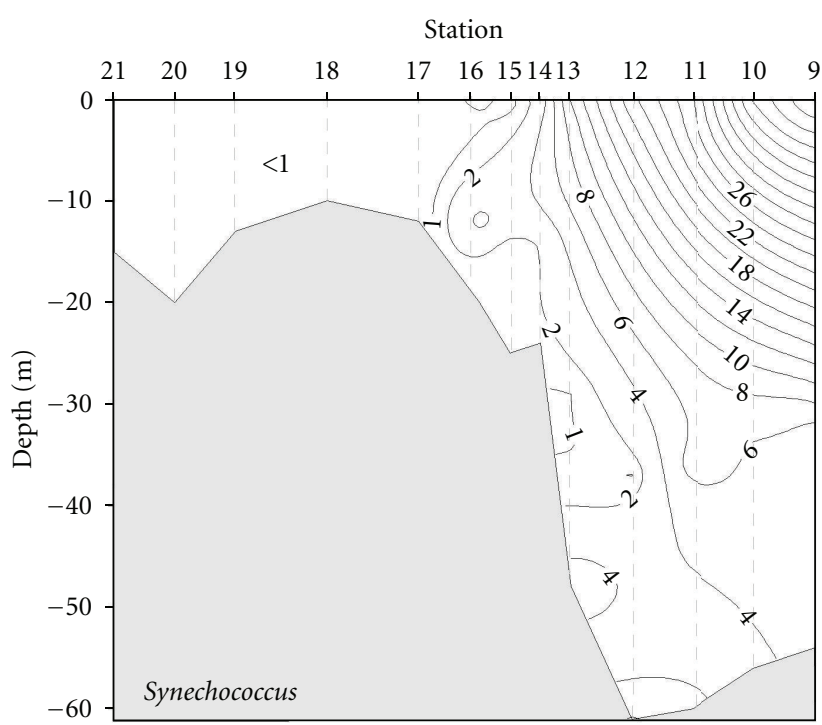

(a) Section I

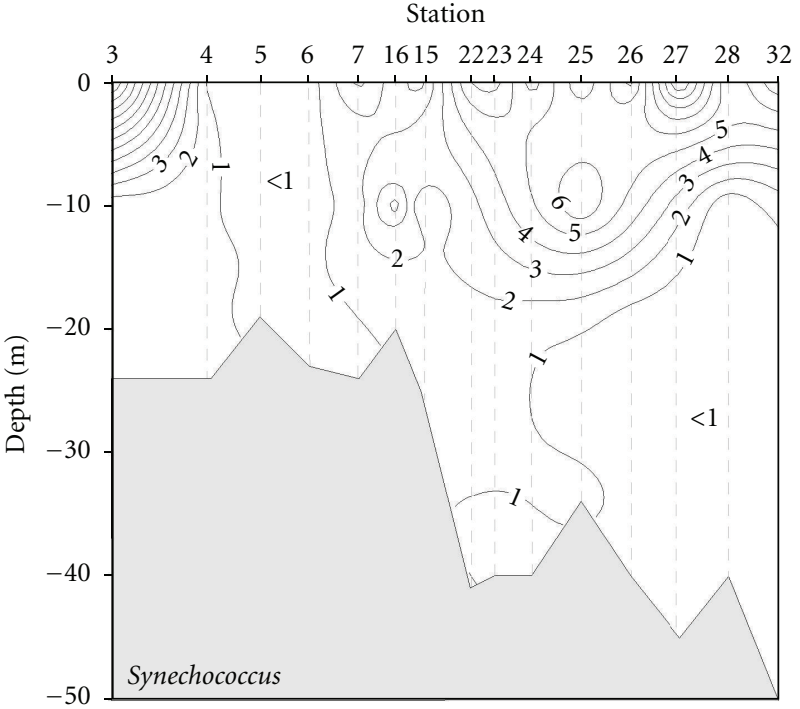

(b) Section II

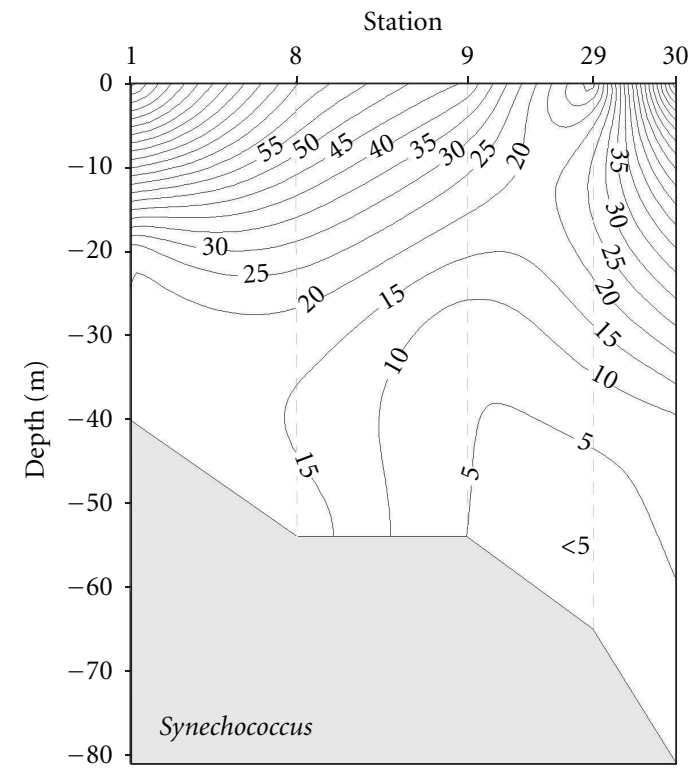

(c) Section III

FIGURE 2: Spatial distribution of Synechococcus $\left(\times 10^{6}\right.$ cells L $\left.^{-1}\right)$ in the Changjiang estuary and its adjacent sea area in June 2006.

2.2. Inorganic Nutrients Analysis. Water samples were filtered immediately after collection through precleaned $0.45 \mu \mathrm{m}$ pore-size cellulose filters. Subsequently, 1-2 drips of saturated $\mathrm{HgCl}$ were added to the filtrate, which was preserved at room temperature in brown bottles for later analysis. Inorganic nutrients (nitrate, nitrite, ammonia, phosphate, and silicate), were determined using spectrophotometry with a SKALAR San ${ }^{\text {plus }}$ Segmented Flow Analyzer (Breda, The Netherlands).

2.3. Picoplankton and Viral Analysis. Samples were fixed for 15 min with paraformaldehyde (final concentration: 1\% $\mathrm{v} / \mathrm{v}$ ) in the dark and then kept frozen in liquid nitrogen until they were analyzed in the laboratory. All of the samples were analyzed with a FACScan instrument (Becton Dickinson, San Jose, CA) within a month of collection. The picophytoplankton was separated into groups according to their specific autofluorescence properties and side scatter differences and their abundance was recorded [12, 21-23]. For the enumeration of heterotrophic bacteria, samples were stained with 1/10000 (v/v) SYBR Green I (Molecular Probes, Inc.) and incubated in the dark for $15 \mathrm{~min}$ before FCM analysis [21]. For virus enumeration, natural samples were diluted using TE buffer $(10 \mathrm{mmol} / \mathrm{L}$ Tris, $1 \mathrm{mmol} / \mathrm{L}$ EDTA, $\mathrm{pH} 8$ ) to $100-1000$ virus s$^{-1}$ using flow cytometry [24]. The diluted virus samples were stained with SYBR Green I (final concentration: $0.5 \times 10^{-4}, \mathrm{v} / \mathrm{v}$ ) for $10 \mathrm{~min}$ in the dark at 


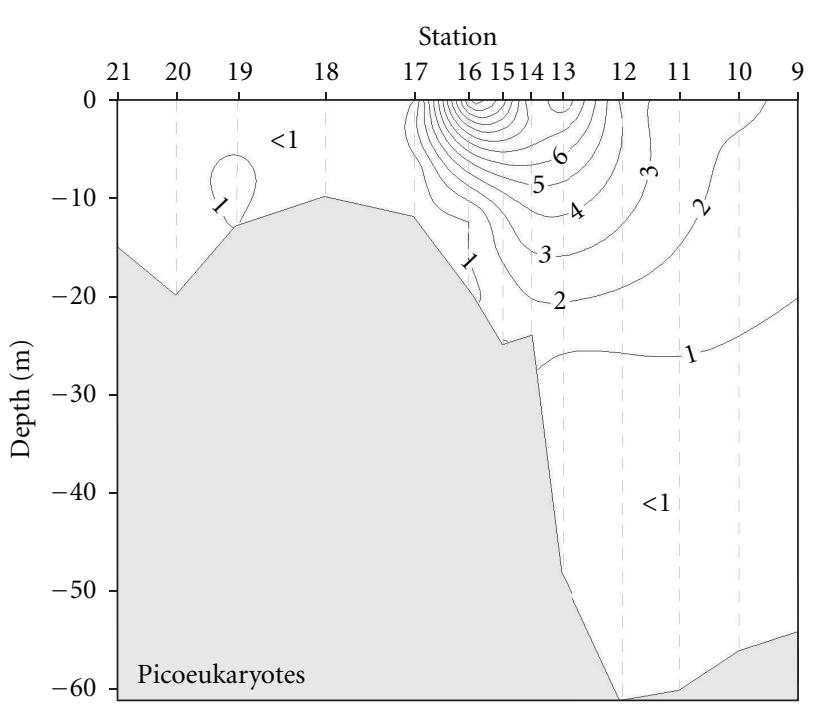

(a) Section I

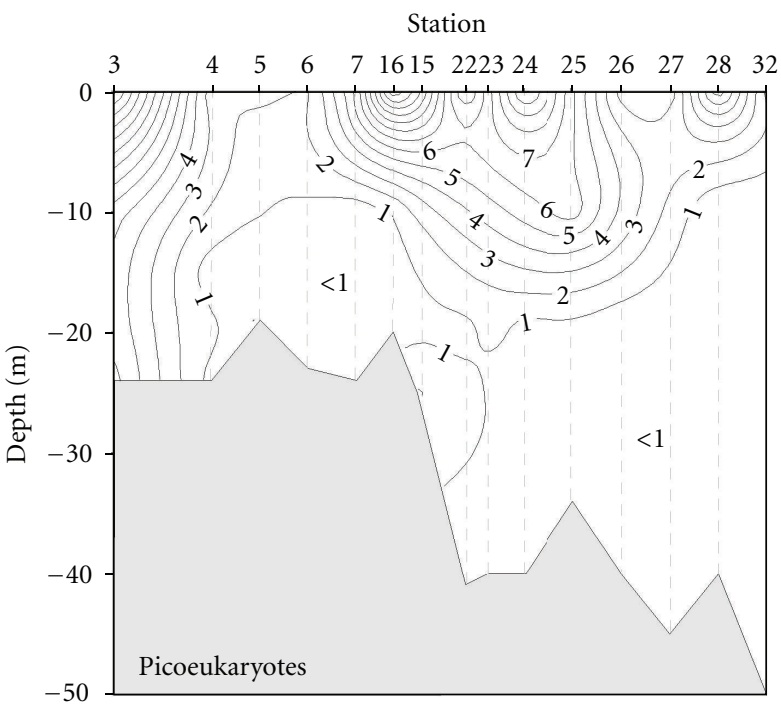

(b) Section II

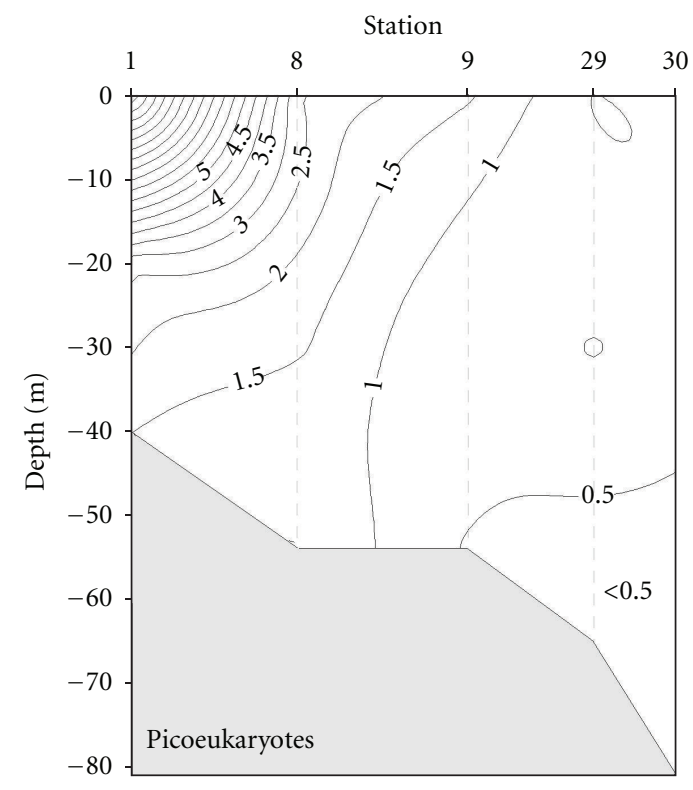

(c) Section III

Figure 3: Spatial distribution of picoeukaryotes $\left(\times 10^{6}\right.$ cells L $\left.\mathrm{L}^{-1}\right)$ in the Changjiang estuary and its adjacent sea area in June 2006.

$80^{\circ} \mathrm{C}$ before $\mathrm{FCM}$ analysis $[15,24]$. Bacteria and viruses were characterized according to their distinctive side scatter and green fluorescence signals, which are related to their size and nucleic acid content, respectively $[15,21]$.

Yellow-green fluorescent beads, $1.002-2.139 \mu \mathrm{m}$ in diameter (Polysciences, Inc.) were added as internal references to calibrate cell fluorescence emissions and light scatter signals and to allow comparisons of fluorescence and cell sizes among samples. All stock solutions were prefiltered through a filter $(0.2 \mu \mathrm{m}$ pore size) before use to avoid contamination. The raw data were processed using CELLQuest software (Becton Dickinson, San Jose, CA). Samples were measured in triplicate to give an estimated precision greater than $8.0 \%$ (relative standard deviation).
2.4. Data Analysis. The data in tables are expressed as mean $\pm \mathrm{SD}$. Coefficient of variation $(\mathrm{CV})$ was calculated by $\mathrm{CV}=$ [SD/Mean] $\times 100 \%$. Regression analysis using the software SPSS 13.0 (SPSS Inc., Chicago, IL) was applied to test if there was any significant relationship between the detected biological groups and the environmental parameters. Pearson's correlation analysis was used to assess major linear relations between the detected biological groups.

\section{Results}

3.1. Environmental Parameters. High values of CV indicated strong changes in salinity, turbidity, and nutrients in the area studied (Table 1). Salinities ranged from 0 to 


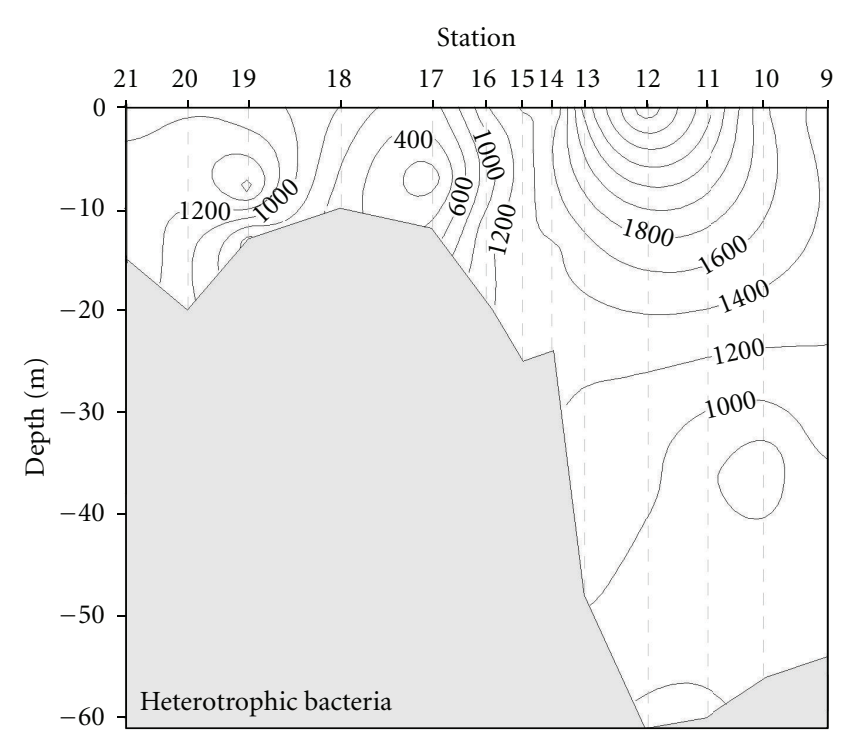

(a) Section I

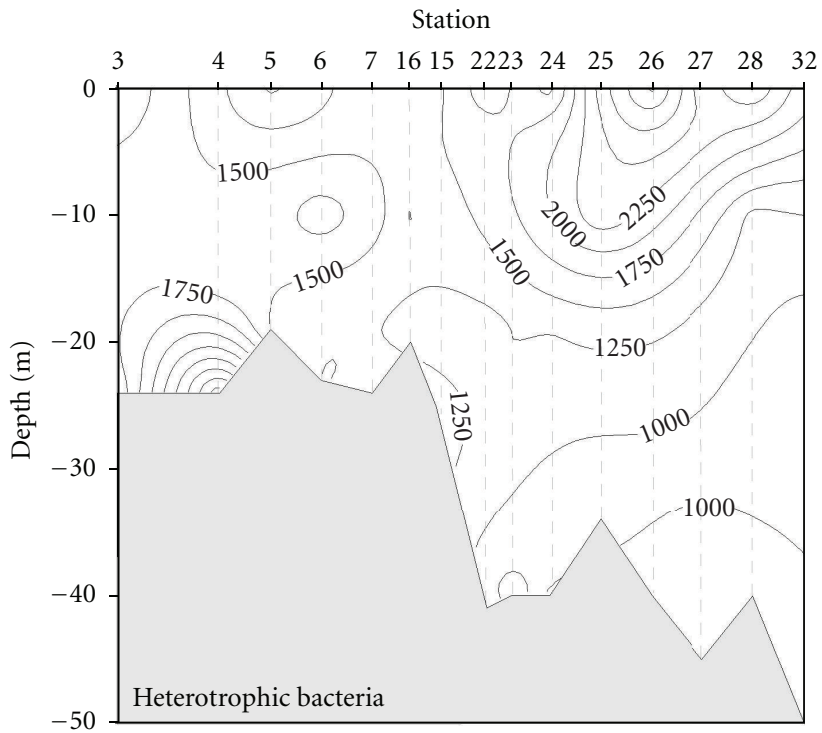

(b) Section II

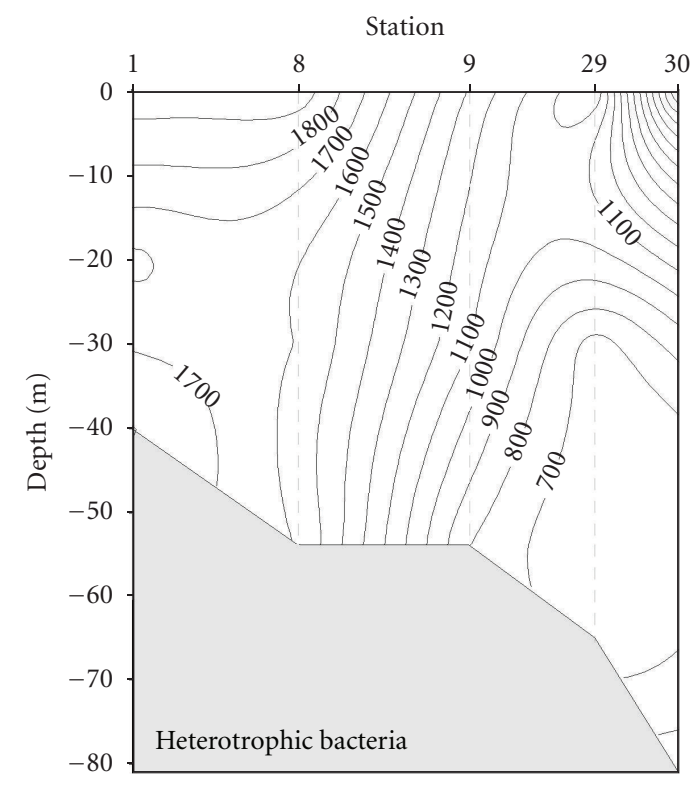

(c) Section III

FiguRE 4: Spatial distribution of heterotrophic bacteria $\left(\times 10^{6}\right.$ cells L $\left.^{-1}\right)$ in the Changjiang estuary and its adjacent sea area in June 2006.

34.42 psu (practical salinity unit) and obviously increased seaward. Turbidity and concentrations of inorganic nutrients decreased rapidly with the distance off the river mouth. The changes in these environmental parameters showed that freshwater from the Changjiang River dramatically affected the water quality in the estuary area, particularly at the stations near the river mouth.

3.2. Spatial Distributions of Picoplankton and Viruses. In the area studied, heterotrophic bacteria and viruses were ubiquitous. Synechococcus and picoeukaryotes could be detected except for a very few samples from stations in the river mouth
(Stations 16-18), while Prochlorococcus in all samples was below detectable level.

Average abundance of Synechococcus was $7.82 \times$ $10^{6}$ cells $\mathrm{L}^{-1}$, with a range of $0-122.22 \times 10^{6}$ cells $\mathrm{L}^{-1}$ (Table 2). Its abundance exhibited distinct spatial differences (Figure 2). The abundance values were $<1 \times 10^{6}$ cells L $^{-1}$ in the water around stations $17-21$ and stations 5 and 6 . At these stations near the river mouth, the abundance differences between the surface and bottom layers were relatively small because their shallow depth allows water to be mixed. At other stations outside the river mouth, the abundance was high at the surface layers and decreased with water depth. 


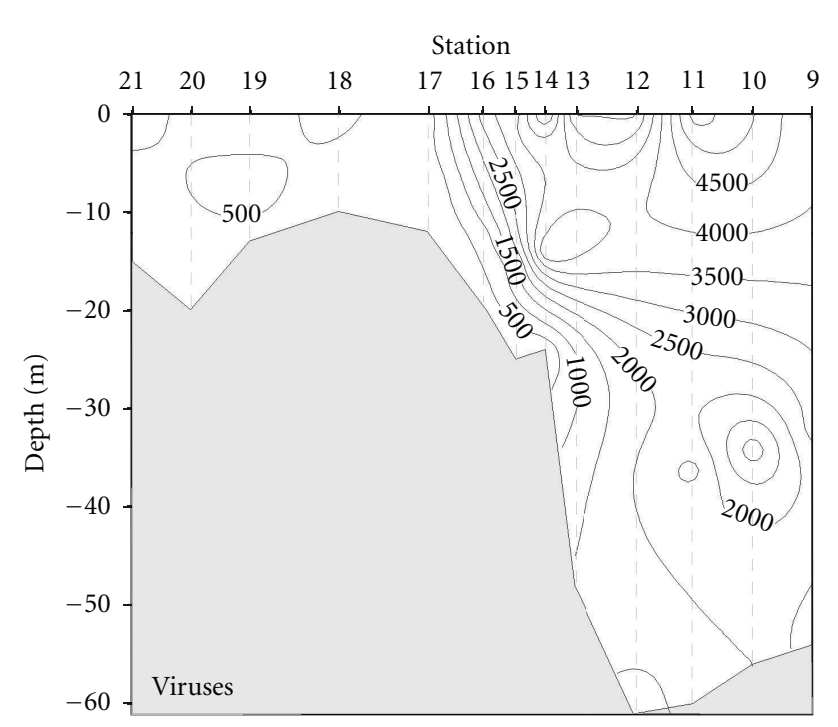

(a) Section I

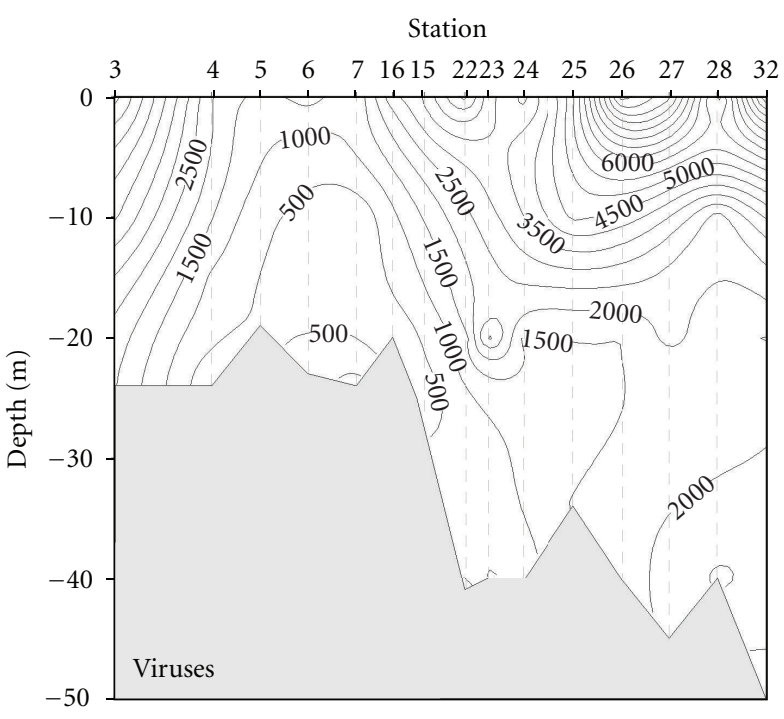

(b) Section II

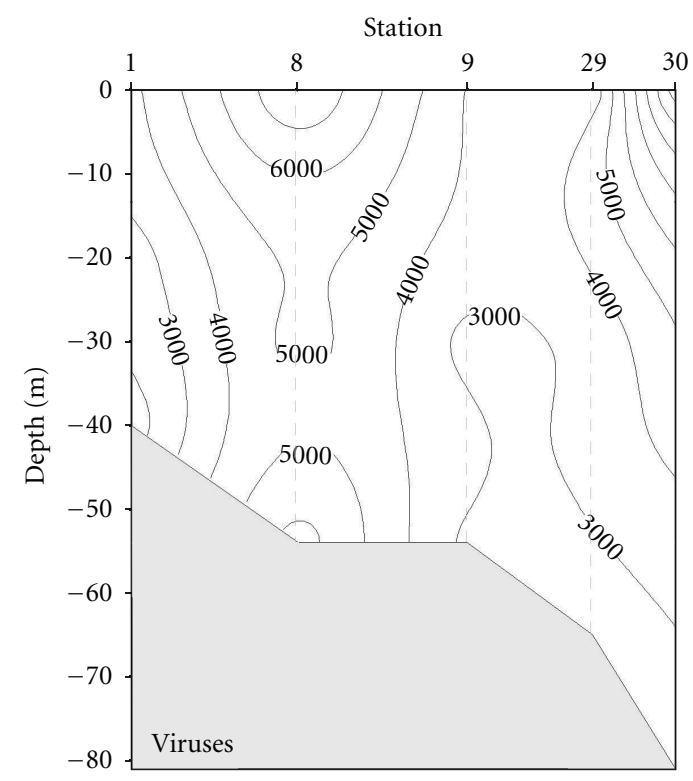

(c) Section III

FIGURE 5: Spatial distribution of viruses $\left(\times 10^{6}\right.$ particles $\left.\mathrm{L}^{-1}\right)$ in the Changjiang estuary and its adjacent sea area in June 2006.

Picoeukaryotes showed a lower average abundance $\left(2.13 \times 10^{6}\right.$ cells $\left.\mathrm{L}^{-1}\right)$ than Synechococcus (Table 2). Its higher abundances $\left(>6 \times 10^{6}\right.$ cells $\left.\mathrm{L}^{-1}\right)$ were mostly recorded from the surface layers at stations 13-16 and 23-25 and the lower abundances $\left(<1 \times 10^{6}\right.$ cells $\left.\mathrm{L}^{-1}\right)$ in the water around stations $17-21$ and $29-31$ in the near bottom water around stations 9-13 and 22-28 (Figure 3). As a whole, the distribution of picoeukaryotes was uneven in different regions and water layers.

Heterotrophic bacteria were quite abundant, with two to three orders of magnitude higher in average abundance $\left(1387 \times 10^{6}\right.$ cells $\left.\mathrm{L}^{-1}\right)$ than those of small autotrophs and showed least variation in abundant (Table 2). Viruses were nearly 2 times more abundance on average (2663 $\times 10^{6}$ particles $\mathrm{L}^{-1}$ ) than heterotrophic bacteria (Table 2). Spatial distribution of heterotrophic bacteria was similar to that of viruses (Figures 4 and 5). Commonly, their vertical distributions were almost even for the stations 17-21 near the river mouth, and for the other stations the abundances decreased with water depth.

\section{Discussion}

Spatial distributions of detected picoplankton groups and viruses featured distinct spatial variability, with different factors exerting control on their growths in different regions. In 


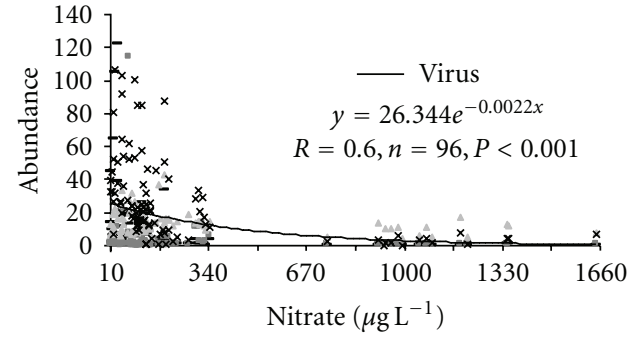

(a)

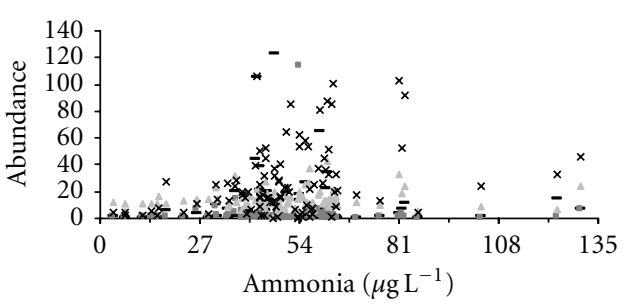

(c)

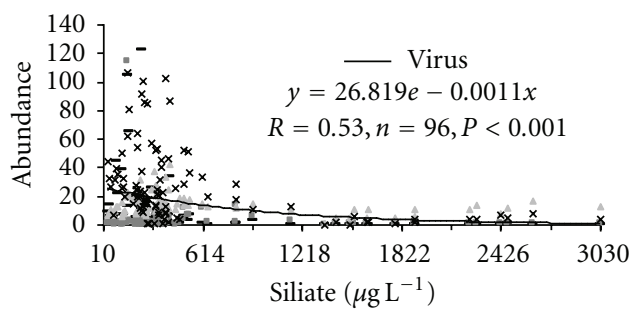

(e)

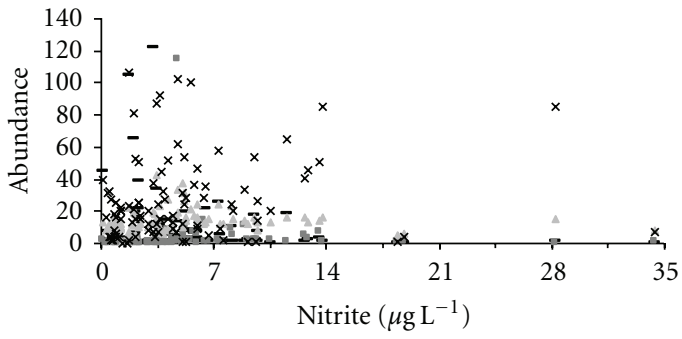

(b)

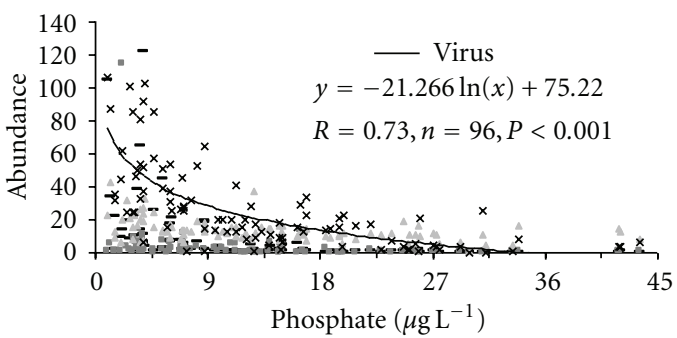

(d)

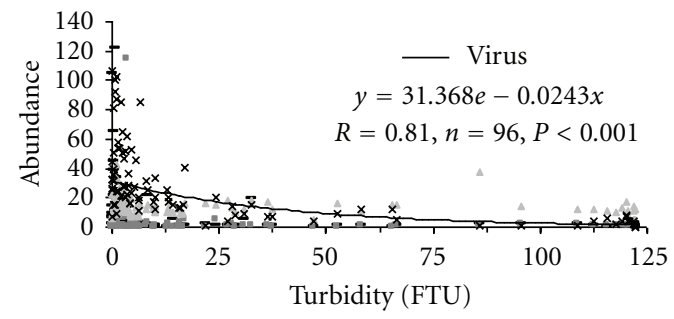

(f)

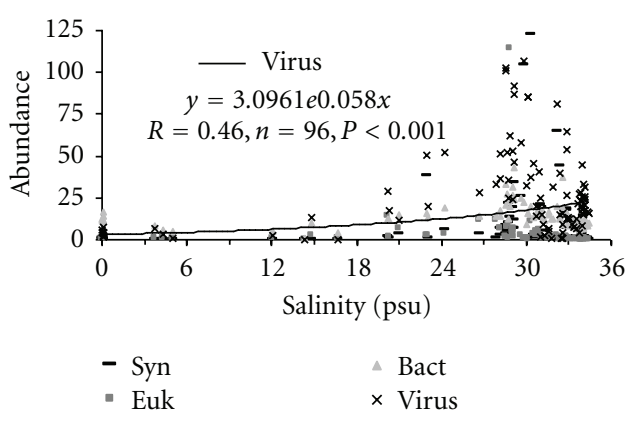

(g)

FIGURE 6: Relationships between the determined biological groups and the environmental parameters (Syn: Synechococcus; Euk: picoeukaryotes; Bact: heterotrophic bacteria).

the turbid river mouth, picoplankton and viral abundances were low, although the concentrations of nutrients were high (Figures 6(a)-6(e)). Unfavorable light conditions because of high turbidity exerted strong limitations to picoplankton $[14,25]$. Further offshore, the abundances increased gradually, with suspended matter settling out. The maximum abundances occurred at about $150 \mathrm{~km}$ (this distance differs somewhat in different groups due to the difference among the groups in the sensitivity to environmental changes) from the river mouth, where turbidity was less than 5 FTU (Formazan Turbidity Units, Figure 6(f)), salinity varied from 28 to $32 \mathrm{psu}$ (Figure $6(\mathrm{~g})$ ), and nutrients largely depleted
(Figures 6(a)-6(e)). Ning et al. [25] pointed out that the front of microzooplankton just appears in these regions because of the availability of abundant preys, which are not tested in this study, however.

Positive linear relations were found between Synechococcus, heterotrophic bacteria, and viruses (Figure 7), and these relations have been reported in many previous studies. Heterotrophic bacteria are dependent on substrates produced by the small primary producers like picophytoplankton (e.g., Synechococcus) due to a tight link between picophytoplankton and dissolved organic matter (DOM) production [13, 26, 27]. Viral lysis of heterotrophic bacteria 


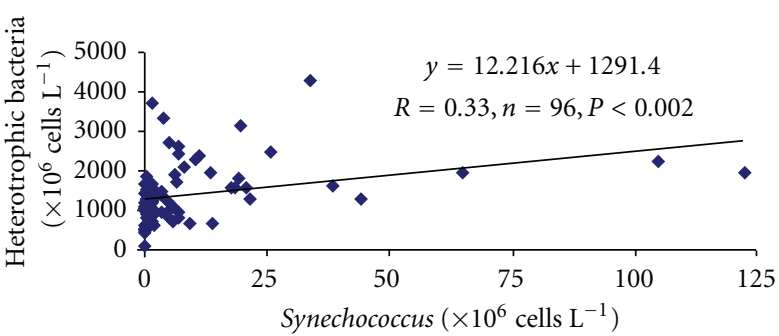

(a)

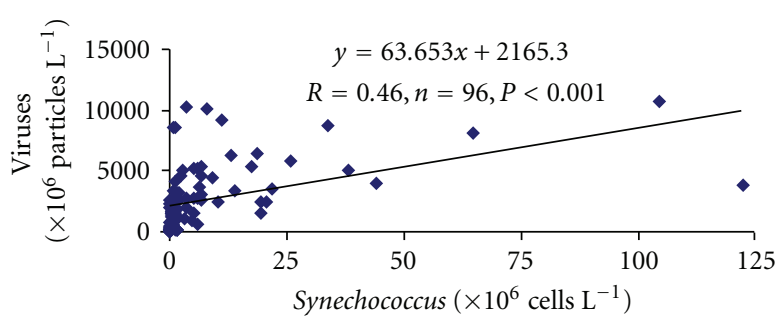

(b)

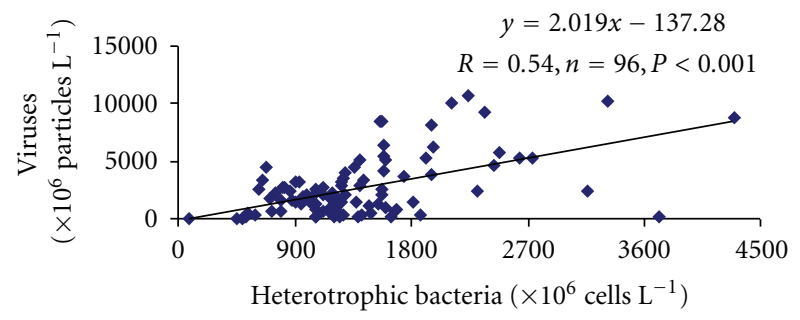

(c)

Figure 7: Linear relations between Synechococcus, heterotrophic bacteria, and viruses.

TABLE 2: List of the measured picoplankton $\left(\times 10^{6}\right.$ cells $\left.\mathrm{L}^{-1}\right)$ and viruses $\left(\times 10^{6}\right.$ particles $\left.\mathrm{L}^{-1}\right)$ in the Changjiang estuary and its adjacent sea area in June 2006.

\begin{tabular}{|c|c|c|c|c|}
\hline Item & Section I & Section II & Section III & Total station \\
\hline Number of sample & 39 & 45 & 15 & 96 \\
\hline Prochlorococcus & Undetected & Undetected & Undetected & Undetected \\
\hline \multicolumn{5}{|l|}{ Synechococcus } \\
\hline Range & $0.00-44.24$ & $0.11-13.23$ & $1.50-122.22$ & $0.00-122.22$ \\
\hline Mean \pm SD & $4.98 \pm 10.03$ & $2.35 \pm 3.02$ & $30.09 \pm 38.02$ & $7.82 \pm 18.64$ \\
\hline $\mathrm{CV}$ & $201 \%$ & $129 \%$ & $126 \%$ & $238 \%$ \\
\hline \multicolumn{5}{|l|}{ Picoeukaryote } \\
\hline Range & $0.11-13.97$ & $0.01-14.21$ & $0.38-10.84$ & $0.01-14.21$ \\
\hline Mean \pm SD & $2.02 \pm 3.11$ & $2.81 \pm 3.84$ & $1.78 \pm 2.61$ & $2.13 \pm 3.11$ \\
\hline $\mathrm{CV}$ & $154 \%$ & $137 \%$ & $147 \%$ & $146 \%$ \\
\hline \multicolumn{5}{|l|}{$\begin{array}{l}\text { Heterotrophic } \\
\text { bacteria }\end{array}$} \\
\hline Range & $84-3159$ & $543-3706$ & $626-2229$ & $84-4287$ \\
\hline Mean \pm SD & $1158 \pm 567$ & $1533 \pm 637$ & $1309 \pm 541$ & $1387 \pm 694$ \\
\hline $\mathrm{CV}$ & $49 \%$ & $42 \%$ & $41 \%$ & $50 \%$ \\
\hline \multicolumn{5}{|l|}{ Virus } \\
\hline Range & $12-5762$ & $85-10266$ & 1479-10642 & $12-10642$ \\
\hline Mean \pm SD & $1604 \pm 1615$ & $2523 \pm 2498$ & $4247 \pm 2471$ & $2663 \pm 2574$ \\
\hline $\mathrm{CV}$ & $101 \%$ & $99 \%$ & $58 \%$ & $97 \%$ \\
\hline
\end{tabular}

potentially benefits Synechococcus by supplying nutrients while simultaneously removing their potential competitors (heterotrophic bacteria) for inorganic and organic nutrients, which is consistent with the view that nutrient cycling by viral lysis of heterotrophic bacteria may control phytoplankton growth and ecosystem scale carbon production [28].

Meanwhile, viral abundance showed a positive correlation with salinity and negative correlations with turbidity and inorganic nutrient (nitrate, phosphate, and silicate) concentrations (Figure 6), indicating that viruses are sensitive to environmental changes $[29,30]$ and their abundance and dynamics may be influenced by these parameters to a large extent [19]. Over the past 20 years, considerable progress has been made in revealing the ecological role of viruses in aquatic ecosystems, but further studies are needed for understanding of the environmental controls on viral 


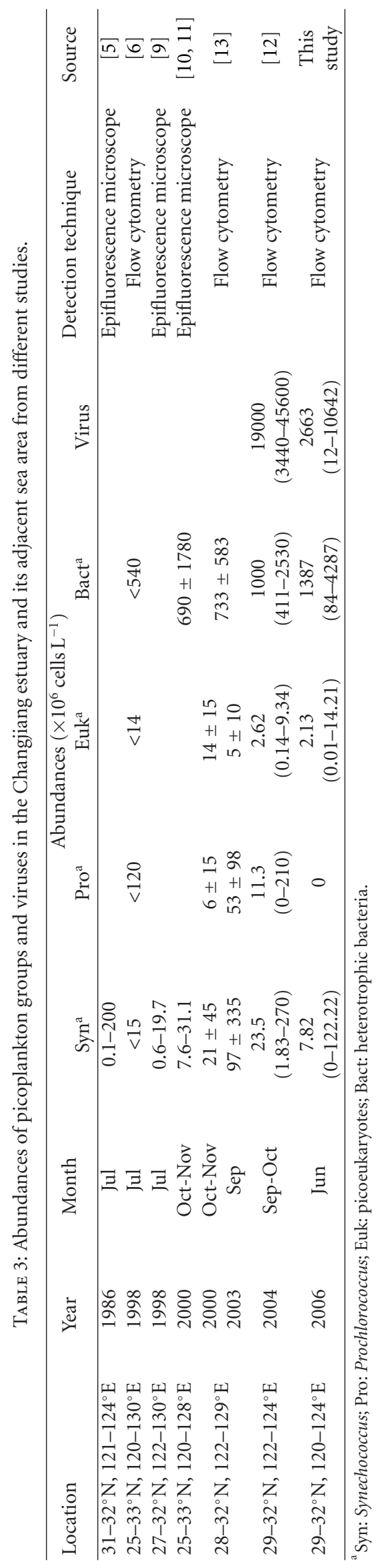


abundance, impacts of viral infection upon host community structure, and roles of viruses in biogeochemical cycles [20].

Prochlorococcus was below detectable level, which may be because of high turbidity and nutrients in this area studied. Prochlorococcus has been found to be more abundant in oligotrophic waters than in eutrophic waters [31]. Pan [12] indicated that Prochlorococcus only presents in waters of salinity $>32.6 \mathrm{psu}$ and suspended sediment concentration $<72 \mathrm{~g} \mathrm{~m}^{-3}$ during a summer cruise in the Changjiang estuary and its adjacent sea area. The key limiting factor for the coastward distribution of Prochlorococcus in the East China Sea was considered to be the movements of the warm water currents, the Kuroshio and the Taiwan Warm Water Currents $[6,7]$.

The abundances of different picoplankton groups obtained in this study were different to a certain extent in the other studies conducted in the Changjiang estuary and its adjacent sea area (Table 3). Particularly, the abundance of viruses remarkably decreased compared to that reported in the literature [12]. The virus-to-bacterium ratio (VBR) was only 1.92 , which is very low given the Changjiang estuary is a eutrophic coastal ecosystem, and a high VBR of 8.7 has been reported in previous study [32]. Jiao et al. [8] suggested that, although causes for the changes in the microbial community structure in the Changjiang estuary could be multiple, the sudden decrease of river runoff and an ensuing intrusion of East China Sea ocean currents were postulated to be among the major ones. The information obtained from this study provides an important and valuable base for evaluating the effects of environmental changes in this area, associated with the construction of the Three Gorges Dam, and long-term monitoring of picoplankton and viruses is necessary.

\section{Acknowledgments}

This work was jointly supported by the Ministry of Science and Technology of China (2002CB412405, 2004CB720505), the Ministry of Education of China (IRT0427), and the Project no. 2008M13 supported by the Special Research Fund for the National Non-Profit Institutes (East China Sea Fisheries Research Institute).

\section{References}

[1] F. Azam and R. E. Hodson, "Size distribution and activity of marine microheterotrophs," Limnology and Oceanography, vol. 22, pp. 492-501, 1977.

[2] J. Sieburth, V. Smetacek, and J. Lenz, "Pelagic ecosystem structure: heterotrophic compartments of the plankton and their relations to plankton size fractions," Limnology and Oceanography, vol. 23, pp. 1256-1263, 1978.

[3] J. B. Waterbury, S. W. Watson, R. R. L. Guillard, and L. E. Brand, "Widespread occurrence of a unicellular, marine, planktonic, cyanobacterium," Nature, vol. 277, no. 5694, pp. 293-294, 1979.

[4] S. W. Chisholm, R. J. Olson, E. R. Zettler, R. Goericke, J. B. Waterbury, and N. A. Welschmeyer, "A novel freeliving prochlorophyte abundant in the oceanic euphotic zone," Nature, vol. 334, no. 6180, pp. 340-343, 1988.
[5] D. Vaulot and N. Xiuren, "Abundance and cellular characteristics of marine Synechococcus spp. in the dilution zone of the Changjiang (Yangtze River, China)," Continental Shelf Research, vol. 8, no. 10, pp. 1171-1186, 1988.

[6] N. Jiao, Y. Yang, H. Koshikawa, and M. Watanabe, "Influence of hydrographic conditions on picoplankton distribution in the East China Sea," Aquatic Microbial Ecology, vol. 30, no. 1, pp. 37-48, 2002.

[7] N. Jiao, Y. Yang, N. Hong et al., "Dynamics of autotrophic picoplankton and heterotrophic bacteria in the East China Sea," Continental Shelf Research, vol. 25, no. 10, pp. 1265-1279, 2005.

[8] N. Jiao, Y. Zhang, Y. Zeng et al., "Ecological anomalies in the East China Sea: impacts of the Three Gorges Dam?" Water Research, vol. 41, no. 6, pp. 1287-1293, 2007.

[9] T. Xiao, H. D. Yue, W. C. Zhang, and R. Wang, "Distribution of Synechococcus spp. and its role in the microbial food loop in the East China Sea," Oceanologia ET Limnologia Sinica, vol. 34, pp. 33-43, 2003.

[10] S. Sun, T. Xiao, and H. D. Yue, "Distribution character of Synechococcus spp. in the East China Sea and the Yellow Sea in autumn and spring," Oceanologia ET Limnologia Sinica, vol. 34, pp. 161-168, 2003.

[11] S. J. Zhao, T. Xiao, and H. D. Yue, "The distribution of heterotrophic bacteria and some related factors in the East China and Yellow Seas during fall," Oceanologia ET Limnologia Sinica, vol. 34, pp. 295-305, 2003.

[12] L. A. Pan, Preliminary study of microbial community structure in the East China Sea shelf area and the frontal region of the northern part of the South China Sea, Dissertation of Master Candidate, East China Normal University, 2005.

[13] L. A. Pan, L. H. Zhang, J. Zhang, J. M. Gasol, and M. Chao, "On-board flow cytometric observation of picoplankton community structure in the East China Sea during the fall of different years," FEMS Microbiology Ecology, vol. 52, no. 2, pp. 243-253, 2005.

[14] Y. Li, D. Li, T. Fang, L. Zhang, and Y. Wang, "Tidal effects on diel variations of picoplankton and viruses in the Changjiang estuary," Chinese Journal of Oceanology and Limnology, vol. 28, no. 3, pp. 435-442, 2010.

[15] D. Marie, C. P. D. Brussaard, R. Thyrhaug, G. Bratbak, and D. Vaulot, "Enumeration of marine viruses in culture and natural samples by flow cytometry," Applied and Environmental Microbiology, vol. 65, no. 1, pp. 45-52, 1999.

[16] Y. H. Yang, Distribution of one group of virus in the eastern East China Sea: results from flow cytometry measurement, Dissertation of Doctoral Candidate, Institute of Oceanology Chinese Academy of Sciences, 2000.

[17] N. Jiao, Y. Zhao, T. Luo, and X. Wang, "Natural and anthropogenic forcing on the dynamics of virioplankton in the Yangtze river estuary," Journal of the Marine Biological Association of the United Kingdom, vol. 86, no. 3, pp. 543-550, 2006.

[18] S. Gao and Y. P. Wang, "Changes in material fluxes from the Changjiang River and their implications on the adjoining continental shelf ecosystem," Continental Shelf Research, vol. 28, no. 12, pp. 1490-1500, 2008.

[19] H. Slováčková, Study of the ecological role of viruses and bacteria in aquatic ecosystems, Dissertation thesis, Masaryk University, Brno, Czech, 2008.

[20] S. Jacquet, T. Miki, R. Noble, P. Peduzzi, and S. Wilhelm, "Viruses in aquatic ecosystems: important advancements of the last 20 years and prospects for the future in the field of microbial oceanography and limnology," Advances in Oceanography and Limnology, vol. 1, no. 1, pp. 97-141, 2010. 
[21] D. Marie, F. Partensky, S. Jacquet, and D. Vaulot, "Enumeration and cell cycle analysis of natural populations of marine picoplankton by flow cytometry using the nucleic acid stain SYBR Green I," Applied and Environmental Microbiology, vol. 63, no. 1, pp. 186-193, 1997.

[22] K. K. Cavender-Bares, E. L. Mann, S. W. Chisholm, M. E. Ondrusek, and R. R. Bidigare, "Differential response of equatorial Pacific phytoplankton to iron fertilization," Limnology and Oceanography, vol. 44, no. 2, pp. 237-246, 1999.

[23] G. A. Tarran, M. V. Zubkov, M. A. Sleigh, P. H. Burkill, and M. Yallop, "Microbial community structure and standing stocks in the NE Atlantic in June and July of 1996," Deep-Sea Research Part II, vol. 48, no. 4-5, pp. 963-985, 2001.

[24] C. P. D. Brussaard, D. Marie, and G. Bratbak, "Flow cytometric detection of viruses," Journal of Virological Methods, vol. 85, no. 1-2, pp. 175-182, 2000.

[25] X. R. Ning, J. X. Shi, Y. M. Cai, and C. G. Liu, "Biological productivity front in the Changjiang Estuary and the Hangzhou Bay and its ecological effects," Acta Oceanologica Sinica, vol. 26, pp. 96-106, 2004.

[26] H. Liu, K. Imai, K. Suzuki, Y. Nojiri, N. Tsurushima, and T. Saino, "Seasonal variability of picophytoplankton and bacteria in the western subarctic Pacific Ocean at station KNOT," DeepSea Research Part II, vol. 49, no. 24-25, pp. 5409-5420, 2002.

[27] H. Liu, M. Dagg, L. Campbell, and J. Urban-Righ, "Picophytoplankton and bacterioplankton in the Mississippi River plume and its adjacent waters," Estuaries, vol. 27, no. 1, pp. 147-156, 2004.

[28] M. G. Weinbauer, O. Bonilla-Findji, A. M. Chan et al., "Synechococcus growth in the ocean may depend on the lysis of heterotrophic bacteria," Journal of Plankton Research, vol. 33, no. 10, pp. 1465-1476, 2011.

[29] S. W. Wilhelm and C. A. Suttle, "Viruses and nutrient cycles in the sea," BioScience, vol. 49, no. 10, pp. 781-788, 1999.

[30] K. E. Wommack and R. R. Colwell, "Virioplankton: viruses in aquatic ecosystems," Microbiology and Molecular Biology Reviews, vol. 64, no. 1, pp. 69-114, 2000.

[31] F. Partensky, W. R. Hess, and D. Vaulot, "Prochlorococcus, a marine photosynthetic prokaryote of global significance," Microbiology and Molecular Biology Reviews, vol. 63, no. 1, pp. 106-127, 1999.

[32] N. Jiao, Y. Zhao, T. Luo, and X. Wang, "Natural and anthropogenic forcing on the dynamics of virioplankton in the Yangtze river estuary," Journal of the Marine Biological Association of the United Kingdom, vol. 86, no. 3, pp. 543-550, 2006. 

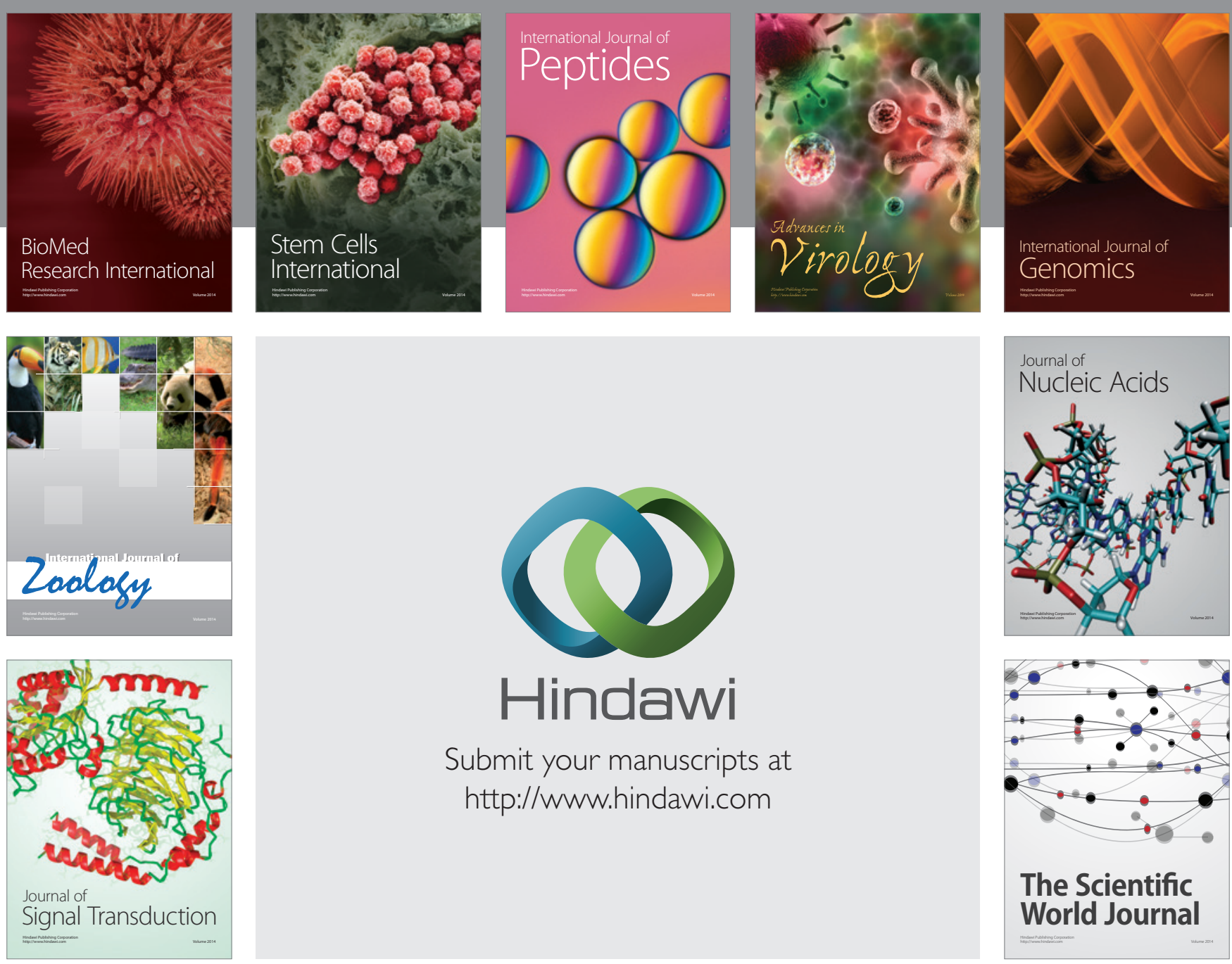

Submit your manuscripts at

http://www.hindawi.com
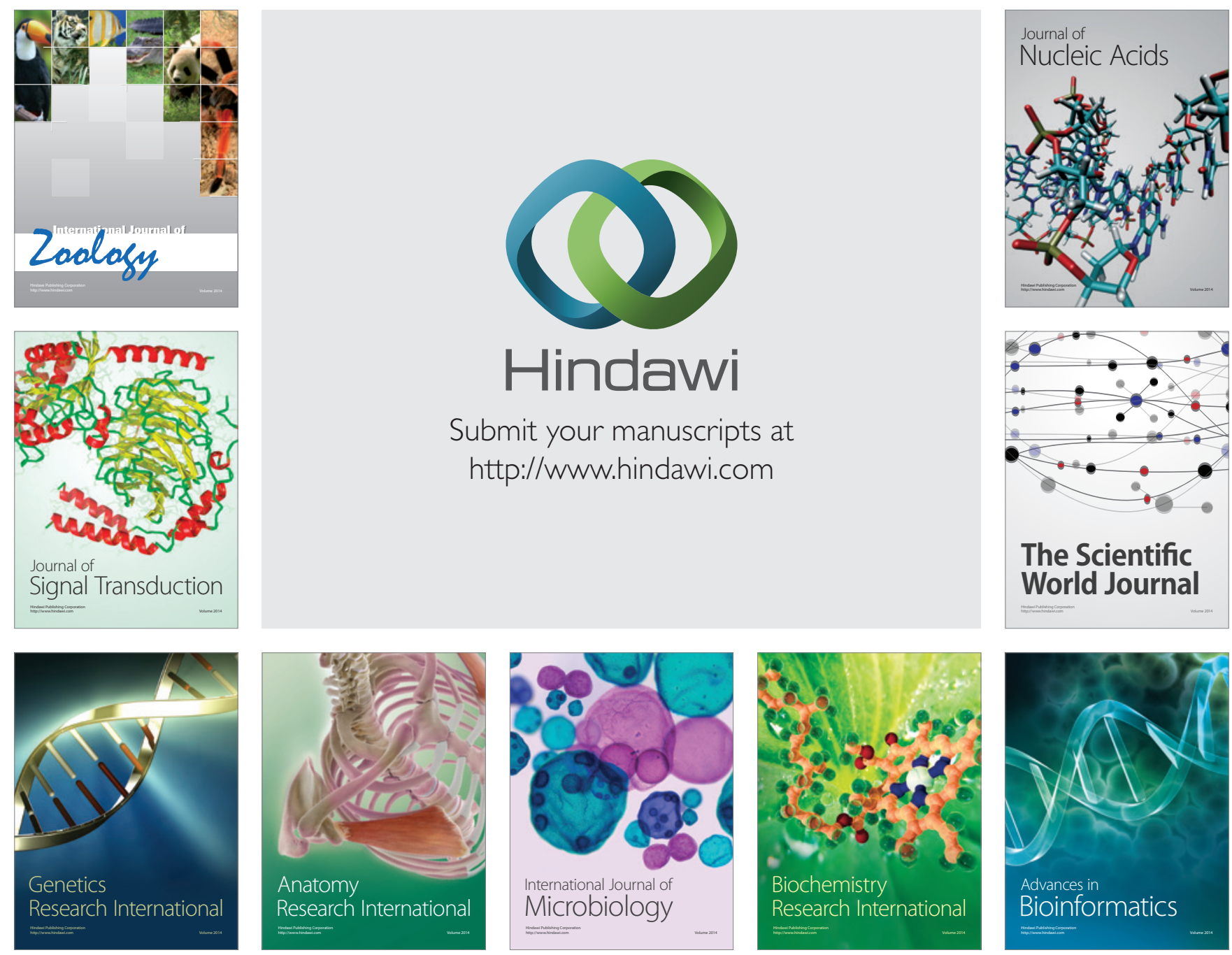

The Scientific World Journal
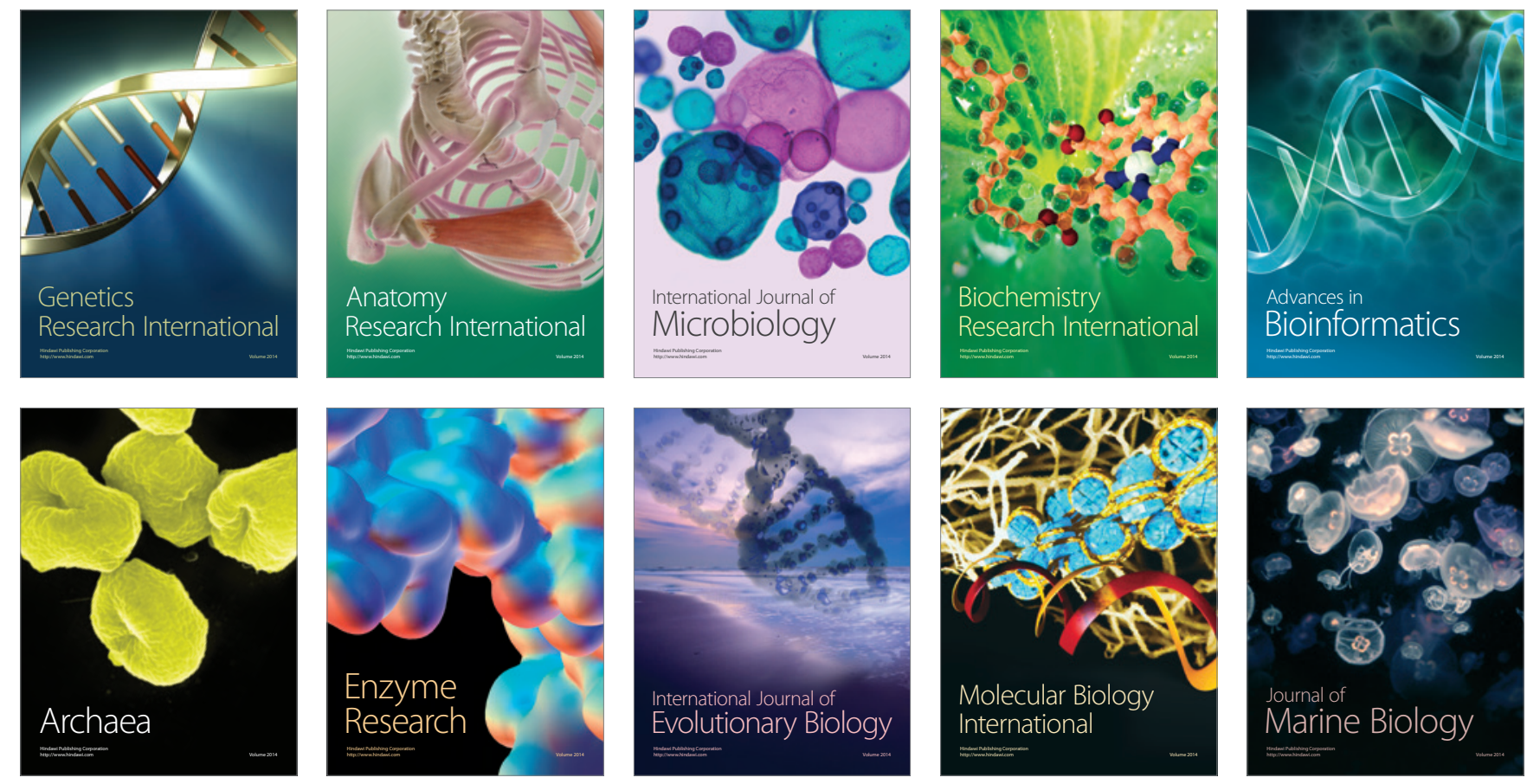